\section{MABR}

1,2

90

\title{
Identifying crucial sustainability assessment criteria for container seaports
}

\author{
Chin-Shan $\mathrm{Lu}$ \\ Department of Logistics and Maritime Studies, \\ The Hong Kong Polytechnic University, Kowloon, Hong Kong \\ Kuo-Chung Shang \\ Department of Transportation Technology, \\ National Taiwan Ocean University, Keelung, Taiwan, and \\ Chi-Chang Lin \\ Department of Transportation and Technology Management, Feng Chia \\ University, Taichung City, Taiwan
}

\begin{abstract}
Purpose - The purpose of this study is to identify crucial sustainability assessment criteria in the context of international port sector.

Design/methodology/approach - Data collection was based on a questionnaire survey from 135 managers and supervisors at major international ports in Taiwan, including Keelung, Taichung and Kaohsiung. A confirmatory factor analysis was conducted to identify crucial sustainability assessment criteria at ports.

Findings - A total of 31 important sustainable assessment criteria were adapted from previous studies in terms of environmental, economic and social issues. Results revealed that social issues with respect to staff job security and safety were ranked as the most important sustainability assessment criteria, followed by environmental protection when handling cargo, facilitation of economic activities, port traffic accidents prevention and cargo handled safely and effectively. In contrary, respondents revealed their less importance in the criteria, namely, mitigating light influence on neighboring residents, considering the arrangement of vehicles when constructing port transportation system, avoiding using unpolluted land in port area and hiring minority groups and consulting interests groups when making port projects. Four sustainability assessment dimensions were identified, namely, environmental material, economic issue, environmental practices and social concerns.

Research limitations/implications - The research findings indicated that economic issue was deemed as the most important dimension of sustainability assessment criteria from a port operator's perspective, followed by environmental practices, social concerns and environmental material. Practical implications for port sustainability assessment were discussed in this research.

Originality/value - Although a majority of previous studies on sustainability assessment have been discussed, there is still a lack of investigation of sustainability assessment in the context of port sector. This study not only develops sustainability assessment attributes but also highlights the important criteria of sustainability assessment. Further, this study identified four crucial sustainability assessment factors, which provide helpful information for port corporations to identify important criteria and policy of sustainability assessment.
\end{abstract}

Keywords Sustainability, Confirmatory factor analysis, Port

Paper type Research paper

Vol. 1 No. 2, 2016

pp. $90-106$

Emerald Group Publishing Limited 2397-3757

DOI 10.1108/MABR-05-2016-0009

(C) Pacific Star Group Education Foundation 


\section{Introduction}

With the rapid development of economic activities and unlimited waste of natural resources, the environment where we dwelled is facing serious deterioration. Over the past decades, consciousness of environmental protection has dramatically risen in the fields of governments and enterprises. World Commission on Environment and Development addressed growing concerns about the deterioration of human environment and natural resources and the consequences of that deterioration for economic and social development in the Brundtland Commission in 1987 (World Commission on Environment and Development, 1987). In addition, an important decision of the United Nations (UN) Climate Change Conference held in Copenhagen, Denmark, in 2009 required developed countries to comply with regulations or laws for decreasing the total amount of emission of carbon dioxide (The UN Global Compact, 2010). Also, the issues of labor safety and community development had drawn much attention and been discussed in the conference. In 2009, 106 UN members have been recognized to establish their national sustainable development policies (The UN Global Compact, 2010). Therefore, business organizations play an important role toward ensuring sustainability along environment, social and economic dimensions.

Ports stand at a vital position between sea and land transportation, which takes up a crucial role in the supply chain in which a large number of people and operational activities are involved. Waterborne commerce is increasing rapidly and presenting ports with challenges that could not even been imagined two decades ago. In 2011, the total volume of cargo shipped by sea reached 16,786 millions of tons and is double that of 1990 (UNCTAD, 2011). To accommodate increases in trade volume, increases in the size of cargo and ships and services requirements, many ports are investing billions of dollars in infrastructures such as deeper channels, larger cranes and other facility and property enhancements. Although many of these investments facilitate improvements in the operational efficiency of existing port operations, many ports also need to physically expand to meet business demands. Even the ports that have traditionally viewed themselves as environmental stewards of coastal resources are finding it challenging to strike a balance between economic, environmental and social issues, i.e. to grow sustainably.

As port corporations are the main operators, an understanding of port operators' sustainability can provide useful information to government to establish the criteria to enhance sustainable development. Nevertheless, sustainability assessment measurement is problematic because of the difficulties in assessing and measuring port accidents or incidents in complex environments. There seems no single measure of sustainability assessment or performance that is unambiguous and wholly resistant to abuse. Therefore, the perceptions of port operators, such as managers, supervisors and senior employees, can offer alternative means for assessing sustainability in the port sector. Accordingly, the objectives of this study are to provide an empirically validated approach to identify sustainability assessment criteria in the container port context and to ascertain whether differences exist between ports.

This research aims to identify crucial sustainability assessment criteria at container seaports in Taiwan. Taiwan is an island-economic entity which is highly dependent on foreign trade. Efficient maritime transport and port operation are essential for ensuring the development of economical activities. According to the Ministry of Transportation and Communications (MOTC) (2016) in Taiwan, more than 99 per cent of annual trade is 
MABR

1,2

92

done by maritime transport and handled at sea ports. Taiwan's international commercial ports, which were originally administered by the four Port Authorities (Keelung, Taichung, Kaohsiung and Hualien) under the Ministry of Transportation and Communications of the ROC, fulfilled the responsibilities of operating port and exercising the public power of shipping, navigation and harbor. To enhance the competitiveness of Taiwan's international commercial ports, Maritime and Port Bureau (MPB), MOTC and Taiwan International Ports Corporation (TIPC) came into being; the former two government authorities take charge of the public power of shipping, navigation and harbor, and the latter is in charge of port operation. Maritime administration covers both administrative supervision and operations. The mission of MPB is to enhance the competitiveness of Taiwan's international commercial ports, instill entrepreneurialism into operations and realize government reorganization priorities. The MPB handles Taiwan's maritime and port affairs. Its former authority over Taiwan's several Harbor Bureaus has been reassigned to TIPC. TIPC's four subsidiaries include the former port authorities of Keelung, Taichung, Kaohsiung and Hualien. This newly established company is tasked to handle comprehensive port operations, enhance operational efficiencies and responsiveness and raise the international profile of Taiwan's international commercial ports and economic growth.

There are five sections in this study. After the introduction section to the study, a review of the literature on criterion of sustainable assessment is presented in the second section. The following section describes the research methodology, including questionnaire survey, sampling technique and analysis methods. The analytical results of important sustainable assessment criteria are then presented. Conclusions drawn from the research findings and their implications for port operation corporations are discussed in the final section.

\section{Literature review \\ Definition of sustainability}

The definition of sustainability had been developed by many of researches and reports. In 1987, UN conference defined sustainability as those that "meet present needs without compromising the ability of future generations to meet their needs"(WCED, 1987). From International Union for Conservation of Nature Resource (IUCN), United Nation Environment Program (UNEP), World Wild Foundation for Nature (WWF) (1991), sustainability was defined as "Improving the quality of human life while living within the carrying capacity of supporting ecosystems". Pronk and Haq (1992) suggested that sustainability is to provide a great opportunity to achieve economic growth of the whole human beings but not for some particular interests groups while not depleting the natural resources and environmental capacity. Pezzey (1992) carried out cost/benefit analysis to evaluate environmental policy for enhancing the protection of environment and the welfare of human beings. UNCSD (1993) stated that human beings possess the right of living in a harmonious way to enjoy healthy and wealthy life and to meet the requirements of developing economy, as well as to ensure the environmental protection of all generations at the same time.

Glavic and Lukman (2007) highlighted three principal crucial components of sustainability, namely, environmental sustainability, economic sustainability and social sustainability in container port operations (Yap and Lam, 2013). They also confirmed the widespread perception of the influences on environment and society 
are trade-offs with economic development (Behrends et al., 2008). A growing number of works on environmental and sustainable management in the port sector have been discussed (Gilman, 2003; Peris-Mora et al., 2005; Darbra et al., 2009). Gul and Cimen (2012) indicated that the mission to achieve port sustainability should be aimed at within an organization and in collaboration with port partners across crucial supply chain members (e.g. ocean carriers, terminal operators, truck companies, stevedoring companies and depot operators).

Accordingly, sustainability refers to the principle of not exceeding the capacity of environment, avoiding the depletion of natural systems and resources, both on quality and quantity to persuade sustainable development by enhancing the efficiency of technology, society and economic effects. Sustainability provides an integrated framework, which not only includes environmental policy but also the policy to develop to improve the welfare of human beings in the whole eco-system.

\section{Sustainability assessment criteria}

A number of international organizations (e.g. The UN Global Compact, OECD and The OECD Guidelines for Multinational Enterprises) have proposed the relevant principles. Sustainability assessment criteria with respect to environment, safety and regulation have been developed by international ports. ISO (International Standard Organization) 14001 evaluated sustainability from five major factors, namely, environmental policy, evaluation of environment, regulation and self-evaluation mechanism, management system and organizational auditing and reporting system (ISO website, 2011). However, the assessment is inconsistent among those countries. Previous studies on sustainability assessment have focused on the aspects of environment and security. Social responsibility also needs to be considered, and it includes the issues of human right, labor interests and social involvement (Marlow, 2008). McIntosh et al. (2003) revealed several aspects to investigate the effects of social responsibility, namely, human rights, work place and employee (safety and security) anti-competing affairs, bribing, corruption, organization government, environment, marketing and consumer issue, community involvement and society development (McIntosh et al., 2003). Accordingly, three sustainability assessment dimensions, namely, economic, social and environmental issues, can be evaluated.

\section{Sustainability assessment criteria in the port sector}

Several international ports have devised the roles and principles for developing sustainability. Sydney ports corporation of Port of Sydney proposed sustainable development projects which focus on consumption of resources (e.g. selection of material, waste management, control of water consumption, control of energy and traffic) and quality of environment (indoor environment, emission control, water quality, land utilization and environmental management) in port areas. Port of Los Angeles set up "sustainability assessment and plan formulation" to express concern over the impacts of port operation on environment, personnel and surrounding environment, whereas Port of Long Beach developed eight major objectives for executing the sustainability assessment. The UK Department of Transport of indicated that the proceeding of port sustainable development policy was classified into three steps in its National Policy Statement for Ports in 2009. These steps include sustainable 
MABR 1,2

\section{4}

policy set up background and goal, definition of sustainable development and identification of major crucial sustainability assessment issues.

Seuring and Muller (2008) found that previous studies primarily focus on environmental issue, and there seems relative little research which have simultaneously considered these three sustainable dimensions such as environmental, social and economical concerns. In the aspect of environmental issue, the related assessment items include air quality, green gas emission, soil and land resources, waste and recycling, coast line sightseeing, lighting, noise, creature diversity, $\mathrm{CO}_{2}$ emission, climate change and water quality. Meanwhile, economical issues consist of assessment items such as the benefits of port operators, economic activities development, fair competition, infrastructure construction, employment and local development, leisure and tourism and investment. Attardi et al. (2012) utilized the Strategic Environmental Assessment to evaluate environmental assessment of pollutant activities in the main industrial port cities of southern Italy. Acciaro et al. (2014) utilized a green strategic objectives framework which combined main functions of a port authority (landlord, regulatory, operator and community manager) for reviewing the influence on environmental sustainability.

As for social issue, assessment items relevant to population, port accessibility, security and safety, neighboring interaction and communication were emphasized. With the increasing awareness and participation of the public, the stakeholders' response to the development of port sustainability has also been notable. Shiau and Chuang (2015) proposed a 34-expert-based port sustainability indicators based on social construction of technology, which was chosen by local legislators and residents. Accordingly, a total of 31 important sustainable assessment criteria were adapted from previous studies, which were divided into environmental, economic and social dimensions and were used in this study.

\section{Methodology \\ Questionnaire design and determination of measures}

This research was accomplished by conducting a questionnaire survey; first, the selection of sustainability assessment criteria by referring to the literatures and on sustainable development researches and reports [Department of Transport (UK), 2009; Marlow, 2008; OECD, 1994; OECD, 1990; Pearce and Warford, 1993], followed by the design of the questionnaire, personal interviews with port managers. The questionnaire design followed the stages outlined by Iacobucci and Churchill (2010). Information sought was first specified, and then the following issues were settled: type of questionnaire and its method of administration, contents of individual questions, form of response to and wording of each question, sequence of questions and physical characteristics of the questionnaire. Moreover, the content validity of the questionnaire in this study was tested through a literature review and interviews with ten port managers who worked at Taiwan International Port Corporations. Questionnaire was initially developed in Chinese and translated to English for examining by port practitioners to ensure that the meaning of the wordings remain the same. Interviews with practitioners resulted in minor modifications to the wording and examples provided in some measurement items, which were finally accepted as possessing content validity. For each item, respondents were asked to indicate the extent to which they agreed the item described its prospective content domain. A five-point rating scale 
was used for each item $(1=$ very unimportant, $2=$ unimportant, $3=$ neither agree nor disagree, $4=$ important and $5=$ very important) to identify the ranking of importance of perceived sustainability assessment criteria. The analysis was carried out using the SPSS 18.0 for windows statistical packages.

\section{Sustainability assessment criteria}

\section{Research sample}

The sample of this research was only focused on the positions such as supervisors, directors and senior director above at Keelung, Taichung and Kaohsiung ports in Taiwan, because they are participating in the implementation of sustainability policies at ports. Hualien port was not considered in this research for the reason that it did not handle container operations. A total of 300 questionnaire surveys (each port sent 100 copies) was sent to managers or supervisors of these three port corporations in June 2011. Although the survey was conducted in 2011, the use of port sustainability assessment criteria in this study was consistent with the sustainability reports in major ports such as Port of Los Angeles (2013), Ports of Toronto (2016), and Port of Antwerp (2016).

Non-response test was conducted to ensure the valid representation of returning questionnaire to population (Armstrong and Overton, 1977). The resulted revealed that the $\chi^{2}$ was not significant among all variables (occupation, title, department and seniority), which stood the sample in this study and can represent the research population. Keelung port received a total of 37 questionnaires, 36 questionnaires were returned from Taichung and 62 questionnaires were returned from Kaohsiung. Ultimately, the total usable responses were 135 out of 300 , and the overall response rate for this study was approximately 45 per cent.

\section{Research methods}

Several research methods were used in this study. Descriptive statistics and exploratory factor analysis was conducted to identify and summarize a large number of sustainability criteria into a smaller, manageable set of underlying factors or dimensions (Hair et al., 2010). Further, a reliability test was conducted to assess whether these safety dimensions were adequate. Confirmatory factor analysis (CFA) was then conducted to verify measurement models. This involved the use of structural equation modelling software AMOS 18.0 to analyze measurement models, assess psychometric properties and specify the relationships among the latent variables and the proposed measures. Finally, one-way analysis of variance (ANOVA) was used to examine whether difference existed between the three designated container ports in the level of importance of the sustainability assessment dimensions.

\section{Results of analyses}

Profile of respondents

As indicated in Table I, results of respondents' profiles and characteristics showed that a vast majority of survey participants (53.3 per cent) were supervisors, followed by first-line managers (29.6 per cent) and senior supervisors (14.1 per cent). Only a few respondents held the positions of director/vice director (1.5 per cent) and chief secretary/ chief engineer/harbor master (1.5 per cent). This study attempted to evaluate the importance of perceived sustainable criteria in all aspects of sustainable dimensions, therefore, the views of managers or supervisors were considered more useful than those of managers, director/vice directors or above. 


\section{MABR \\ 1,2}

Characteristic

No. of respondents

$(\%)$

Job title

1.5

\section{6}

President/Vice president

Chief secretary/Chief engineer/Harbor master

Senior director

Director

Supervisor

2

2

19

72

40

Years of working experience

10 years or less

11-20 years

20 years or less

\section{2}

43

80

Work department

Operations

Warehousing

Secretarial department

Harbor affairs

Information technology

Harbor construction

Table I.

Profile of

respondents
Human resource

Navigation

Research and development
1.5

14.1

53.3

29.6

8.6

31.9

59.5

40.8

12.6

11.1

9.6

8.9

6.7

4.4

3.7

2.2

Descriptive results indicated that a majority of respondents (59.5 per cent) served more than 20 years in port, whereas 31.9 per cent of respondents have been working in ports for 11-20 years. Only 8.6 per cent of respondents have been working in ports for less than 10 years. Furthermore, the results also revealed that 40.8 per cent of respondents had worked in relevant operation departments, whereas 12.6 per cent of respondents served in warehousing department, 11.1 per cent in secretarial department, 9.6 per cent in harbor affairs department, 8.9 per cent in information department, 6.7 per cent in harbor construction department, 4.4 per cent in human resource department, 3.7 per cent in navigation administration and 2.2 per cent in research department.

Relative importance of port sustainability assessment criteria

This study investigated crucial port sustainability assessment criteria along three sustainable dimensions, namely, economic, social and environmental dimensions. Respondents were asked to provide information about their perceived sustainable criteria, and 31 perceived sustainable criteria were ranked. According to their aggregated scores for agreement with the 31 sustainable criteria, respondents' perceptions ranged from 3.56 to 4.56, which suggested that the issues of sustainability are very important in port operations (Table II). Results revealed that social issues with respect to employee job security and safety was ranked the most important sustainable assessment criterion, followed by considering environmental protection when handling cargo, facilitating to economic activities, port traffic accidents prevention and ensuring cargo handled safely and effectively, as these items' mean scores were 4.48 or above. 


\begin{tabular}{|c|c|c|c|c|}
\hline Port sustainability assessment criterion & Mean $^{\mathrm{a}}$ & $\mathrm{SD}^{\mathrm{b}}$ & Rank & ment \\
\hline Employee job security and safety & 4.56 & 0.73 & 1 & criteria \\
\hline \multicolumn{4}{|l|}{ Considering environmental protection when handling } & \multirow{4}{*}{97} \\
\hline Facilitating to economic activities & 4.50 & 0.72 & 3 & \\
\hline Port traffic accidents prevention & 4.48 & 0.70 & 4 & \\
\hline Ensuring cargo handled safely and effectively & 4.48 & 0.74 & 5 & \\
\hline Ensuring port area safety and orders & 4.44 & 0.71 & 6 & \\
\hline Developing approaches against rapid climate change & 4.43 & 0.82 & 7 & \\
\hline Disposing of effluents & 4.39 & 0.73 & 8 & \\
\hline Establishing port development funding & 4.35 & 0.77 & 9 & \\
\hline Maintaining air quality & 4.33 & 0.76 & 10 & \\
\hline Strengthening port infrastructure construction & 4.32 & 0.85 & 11 & \\
\hline Concerning over benefits of port operators & 4.31 & 0.70 & 12 & \\
\hline Offering employment opportunities & 4.27 & 0.77 & 13 & \\
\hline Maintaining water quality & 4.22 & 0.83 & 14 & \\
\hline Decreasing greenhouse gas emission & 4.18 & 0.87 & 15 & \\
\hline Landscape improvement & 4.16 & 0.76 & 16 & \\
\hline Encouraging foreign direct investment & 4.13 & 0.84 & 17 & \\
\hline Flood avoidance in land side operation area & 4.07 & 0.91 & 18 & \\
\hline Avoiding environmental destruction when dredging & 4.05 & 0.85 & 19 & \\
\hline Decreasing noise pollution & 4.04 & 0.90 & 20 & \\
\hline Using environmental-friendly material in port construction & 3.97 & 0.92 & 21 & \\
\hline Encouraging using recyclable material & 3.96 & 0.86 & 22 & \\
\hline Supporting tourism industry development & 3.93 & 0.87 & 23 & \\
\hline Ecological environment protection in port area & 3.90 & 0.91 & 24 & \\
\hline Recognizing requirements of neighboring community & 3.88 & 0.81 & 25 & \\
\hline Historic relics protection & 3.71 & 0.92 & 26 & \\
\hline Mitigating light influence on neighboring residents & 3.70 & 0.93 & 27 & \\
\hline \multicolumn{5}{|l|}{ Considering the arrangement of vehicles when } \\
\hline constructing port transportation & 3.64 & 0.89 & 28 & \\
\hline Avoiding using unpolluted land in port area & 3.64 & 1.09 & 29 & \\
\hline Hiring minority groups & 3.62 & 0.79 & 30 & \\
\hline Consulting interests groups when making port projects & 3.56 & 0.83 & 31 & $\begin{array}{l}\text { Table II. } \\
\text { Importance of port }\end{array}$ \\
\hline \multicolumn{4}{|c|}{$\begin{array}{l}\text { Notes: a The ratings were based on the mean scores obtained from a Likert scale ranging from } 1 \text { (very } \\
\text { unimportant) to } 5 \text { (very important); }{ }^{b} \mathrm{SD}=\text { standard deviation }\end{array}$} & $\begin{array}{r}\text { sustainability } \\
\text { assessment criteria }\end{array}$ \\
\hline
\end{tabular}

In contrast, respondents showed the following five sustainability items were less important:

(1) mitigating light influence on neighboring residents;

(2) considering the arrangement of vehicles when constructing port transportation system;

(3) avoiding using unpolluted land in port area;

(4) hiring minority groups; and

(5) consulting interests groups when making port projects, which means that scores were below 3.7. 
MABR

1,2

Accordingly, the research finding reflected that port corporations have emphasized on the sustainability assessment criteria such as employee work environmental safety and impacts on environment when handling cargo in port operations.

\section{Factor analysis and reliability test}

This study used a factor analysis method to summarize a large number of sustainability assessment criteria by grouping them into a smaller number of underlying dimensions called critical factors. VARIMAX rotation technique was applied to transform a set of interrelated variables into a set of unrelated linear combinations of these variables. The data were deemed appropriate for analysis, according to the Kaiser-Meyer-Olkin sampling adequacy value of 0.918 (Hair et al., 2010). The Bartlett Test of sphericity was significant $\left(\chi^{2}=4,104, p<0.00\right)$ and well above the recommended level. Only variables with a factor loading greater than 0.5 were extracted to aid interpretation (Hair et al., 2010). Having eigenvalues greater than 1 was used as the criterion to determine the number of factors in each data set (Iacobucci and Churchill, 2010). In addition, a reliability test based on Cronbach's $\alpha$ was used to test the internal consistency of questionnaire responses. The larger the absolute size of the factor loading, the more important the loading is in interpreting the factor matrix. However, the interpretability of this solution was rendered problematic because of one item being loaded on two factors and their factor loading being less than 0.5 . This item which was subsequently removed from further analysis was "considering the arrangement of vehicles when constructing port transportation system”.

Subsequent analysis of the 30 remaining items yielded four factors or dimensions, which accounted for approximately 64.251 per cent of the total variance. A reliability test based on a Cronbach's $\alpha$ statistic was used to test whether these factors were consistent and reliable. The reliability factor of each factor was well above the value of 0.85 , considered to indicate a satisfactory level of reliability in a basic research (Nunnally, 1978; Hair et al., 2010). The factors were described as below:

(1) Factor 1, environmental material: This consisted of 11 items, namely, historic relics protection, avoiding using unpolluted land in port area, using environmental-friendly material in port construction, encouraging using recyclable material, ecological environment protection in port area, mitigating light influence on neighboring residents, landscape improvement, avoiding environmental destruction when dredging, disposing of effluents, decreasing noise pollution and maintaining water quality. Historic relics protection had the highest factor loading (0.753) on this dimension and accounted for 44.698 per cent of the total variance. These items are port environmental material-related activities. Therefore, the factor was identified as environmental material dimension.

(2) Factor 2, economic issue: This consisted of six items, facilitating to economic activities, concerning over the benefits of port operators, ensuring cargo handled safely and effectively, establishing port development funding, supporting tourism industry development, offering employment opportunities and encouraging foreign direct investment. Facilitating to economic activities had highest factor loading $(0.875)$ on this dimension and accounted for 8.806 per cent of the total variance. These items are economic 
issues-related activities. Therefore, the factor was identified as economic issue dimensions.

(3) Factor 3, environmental practices factor: This consisted of six items, strengthening port infrastructure construction, developing approaches against rapid climate change, flood avoidance in land side operation area, maintaining air quality, decreasing greenhouse gas emission and considering environmental protection when handling cargo. Strengthening port infrastructure construction scored the highest factor loading $(0.812)$ on this dimension and accounted for 6.320 per cent of the total variance. These items are environmental practice-related activities. Therefore, the factor was identified as environmental practices dimensions.

(4) Factor 4, social concerns: This consisted of six items, recognizing requirements of neighboring community, employee job security and safety, port traffic accidents prevention, ensuring port area safety and orders, hiring minority groups and consulting interests groups when making port project. Recognizing requirements of neighboring community had the highest factor loading on this dimension (0.782) and accounted for 4.158 per cent of the total variance. These items are social-related activities. Therefore, the factor was identified as social concern dimension. As indicated in Table III, Factor 2, economic issue, had the highest average score (mean $=4.344$ ), and this was perceived by respondents to be the most important of these four factors.

\section{Confirmatory factor analysis}

Confirmatory factor analysis allows tests to be conducted for uni-dimensionality, convergent validity and divergent validity of the scales used in a study. Uni-dimensionality can be described as the existence of one construct (or latent variable) underlying a set of items. One of the loadings in each construct can be set to a fixed value of 1.0 to make the construct comparable (Koufteros, 1999). CFA using AMOS 18.0 was performed to ensure the validity of the measurement scale (Anderson and Gerbing, 1998).

A number of goodness-of-fit indices recommended by many researchers were used to assess the fit and uni-dimensionality of the measurement model (Bagozzi and Yi, 1988; Hu and Bentler, 1995; Kline, 1998; Koufteros, 1999). The results, as shown in Table IV, provided an adequate model fit $\left(\chi^{2} / \mathrm{df}=1.80\right.$; goodness-of-fit index $(\mathrm{GFI})=0.91$; adjusted goodness-of-fit index $(\mathrm{AGFI})=0.87$; Tucker-Lewis index $(\mathrm{TLI})=0.95$; normed fit index $(\mathrm{NFI})=0.91$; root mean square residual $(\mathrm{RMR})=0.02$; and root mean square error of approximation (RMSEA) $=0.07$ ), indicating that the proposed model was purified and credible. (Bollen, 1989; Hair et al., 2010).

Convergent validity can be tested by $t$-values that are all statistically significant on the factor loadings. The $t$-value, in the AMOS output result indicates the critical ratio $(\mathrm{CR})$, which represents the parameter estimated divided by its standard error. As a rule of thumb, the value of $\mathrm{CR}$ needs to be greater than 2.00 or smaller than -2.00 for the estimate to be acceptable (Koufteros, 1999; Byrne, 2001; Hair et al., 2010). Results showed that all CR values of all measurements were significant at the 0.05 level, in effect confirming that all criteria measured the same construct and provide satisfactory evidence of the convergent validity and uni-dimensionality of each construct (Anderson and Gerbing, 1998). Moreover, item reliability $\left(R^{2}\right)$ can be used to measure the reliability 
MABR 1,2

Table III.

Factor analysis of sustainability indicator

\begin{tabular}{|c|c|c|c|c|}
\hline Items & Factor 1 & Factor 2 & Factor 3 & Factor 4 \\
\hline Historic relics protection & 0.753 & 0.115 & 0.170 & 0.230 \\
\hline Avoiding using unpolluted land in port area & 0.752 & 0.065 & 0.155 & 0.253 \\
\hline $\begin{array}{l}\text { Using environmental-friendly material in port } \\
\text { construction }\end{array}$ & 0.747 & 0.046 & 0.214 & 0.166 \\
\hline Encouraging using recyclable material & 0.737 & 0.112 & 0.240 & 0.141 \\
\hline Ecological environment protection in port area & 0.732 & 0.125 & 0.276 & 0.289 \\
\hline Mitigating light influence on neighboring residents & 0.679 & 0.208 & 0.225 & 0.260 \\
\hline Landscape improvement & 0.665 & 0.305 & 0.195 & 0.274 \\
\hline Avoiding environmental destruction when dredging & 0.659 & 0.259 & 0.388 & 0.190 \\
\hline Disposing of effluents & 0.596 & 0.286 & 0.327 & 0.317 \\
\hline Decreasing noise pollution & 0.566 & 0.407 & 0.266 & 0.229 \\
\hline Maintaining water quality & 0.557 & 0.209 & 0.332 & 0.211 \\
\hline Facilitating to economic activities & 0.055 & 0.875 & 0.122 & 0.178 \\
\hline Concerning over benefits of port operators & 0.208 & 0.850 & 0.054 & 0.173 \\
\hline Ensuring cargo handled safely and effectively & 0.167 & 0.670 & 0.142 & 0.284 \\
\hline Establishing port development funding & 0.210 & 0.633 & 0.250 & 0.142 \\
\hline Supporting tourism industry development & 0.240 & 0.619 & 0.071 & 0.151 \\
\hline Offering employment opportunities & 0.260 & 0.590 & 0.195 & 0.315 \\
\hline Encouraging foreign direct investment & -0.044 & 0.556 & 0.237 & 0.152 \\
\hline Strengthening port infrastructure construction & 0.229 & 0.179 & 0.812 & 0.133 \\
\hline Developing approaches against rapid climate change & 0.203 & 0.211 & 0.803 & 0.092 \\
\hline Flood avoidance in land side operation area & 0.395 & 0.047 & 0.723 & 0.196 \\
\hline Maintaining air quality & 0.385 & 0.204 & 0.670 & 0.116 \\
\hline Decreasing greenhouse gas emission & 0.444 & 0.165 & 0.653 & 0.140 \\
\hline $\begin{array}{l}\text { Considering environmental protection when } \\
\text { handling cargo }\end{array}$ & 0.256 & 0.321 & 0.624 & 0.233 \\
\hline $\begin{array}{l}\text { Recognizing requirements of neighboring } \\
\text { community }\end{array}$ & 0.296 & 0.179 & 0.118 & 0.782 \\
\hline Employee job security and safety & 0.245 & 0.296 & 0.148 & 0.739 \\
\hline Port traffic accidents prevention & 0.233 & 0.292 & 0.191 & 0.726 \\
\hline Ensuring port area safety and orders & 0.193 & 0.272 & 0.246 & 0.722 \\
\hline Hiring minority groups & 0.365 & 0.135 & 0.084 & 0.642 \\
\hline $\begin{array}{l}\text { Consulting interests groups when making port } \\
\text { projects }\end{array}$ & 0.265 & 0.248 & 0.085 & 0.635 \\
\hline Mean & 3.962 & 4.344 & 4.318 & 4.096 \\
\hline $\mathrm{SD}$ & 0.234 & 0.126 & 0.173 & 0.254 \\
\hline Eigenvalues & 13.490 & 2.642 & 1.896 & 1.247 \\
\hline Percentage variance $(\%)$ & 44.698 & 8.806 & 6.320 & 4.158 \\
\hline Accumulated percentage variance $(\%)$ & 44.698 & 53.774 & 60.093 & 64.251 \\
\hline Cronbach's alpha & 0.939 & 0.871 & 0.905 & 0.894 \\
\hline
\end{tabular}

of a particular observed variable or item (Koufteros, 1999). Results revealed that all $R^{2}$ values were greater than 0.5 , providing evidence of convergent validity (Carr and Pearson, 1999; Hair et al., 2010). Discriminate validity was assessed by comparing the average variance extracted (AVE) with the squared correlation between constructs. Discriminate validity exists if the items share more common variance with their respective construct than any variance that the construct shares with other constructs (Fornell and Larcker, 1981; Koufteros, 1999). 


\begin{tabular}{lcr}
\hline Measures & Criteria & Results \\
\hline$\chi^{2}$ & - & 151.76 \\
$\chi^{2} /$ df & $<2$ & 1.80 \\
$p$ value & $>0.05$ & 0.00 \\
GFI & $>0.9$ & 0.91 \\
AGFI & $>0.9$ & 0.87 \\
TLI & $>0.9$ & 0.95 \\
NFI & $>0.9$ & 0.91 \\
RMR & Close to 0 & 0.02 \\
RMSEA & $<0.08$ & 0.07
\end{tabular}

\section{Sustainability assessment criteria}

0.00

0.91

0.87

0.95

0.91

0.02

Notes: GFI: goodness-of-fit index; AGFI: adjusted goodness-of-fit index; TLI: Tucker-Lewis index; NFI: normed fit index; RMR: root mean square residual; RMSEA: root mean square error of approximation

Table IV.

Goodness-of-fit indicator

As shown in Table V, results indicated that the highest squared correlation was 0.477 , which was observed between carrier collaboration and supplier collaboration. The value was significantly lower than their individual AVE values of 0.500 and 0.520 , respectively. The results demonstrated evidence of discriminate validity for the study variables.

Composite reliability provides a measure of the internal consistency and homogeneity of the items comprising a scale (Iacobucci and Churchill, 2010). It means that a set of latent criteria of construct are consistent in their measurement. The reliability of construct can be estimated using AMOS output results. This reliability is the degree to which a set of two or more criteria share the measurement of a construct. Highly reliable constructs are those in which the criteria are highly inter-correlated, indicating that they are all measuring the same latent construct. The range of values for reliability is between 0 and 1 . Results also indicated that the reliability of the constructs of environmental material, economic issue, environmental practices and social concerns were $0.904,0.867,0.863$ and 0.858 , respectively. All constructs exceeded the recommended level of 0.60 (Bagozzi and Yi, 1988; Sanchez-Rodriguez et al., 2005; Hair et al., 2010).

Differences in port corporations' perceptions of sustainability assessment criteria To examine the perceived differences of sustainability assessment dimensions between Keelung port, Taichung port and Kaohsiung port, ANOVA was performed based on a

\begin{tabular}{lccccc}
\hline Dimensions & AVE $^{\mathrm{a}}$ & $\begin{array}{c}\text { Environmental } \\
\text { material }\end{array}$ & $\begin{array}{c}\text { Economic } \\
\text { issue }\end{array}$ & $\begin{array}{c}\text { Environmental } \\
\text { practices }\end{array}$ & Social concern \\
\hline Environmental material & 0.501 & 1 & & & \\
Economic issue & 0.500 & $0.577^{* *}(0.332)^{\mathrm{b}}$ & 1 & & \\
Environmental practices & 0.520 & $0.691^{* *}(0.477)$ & $0.548^{* *}(0.300)$ & 1 & \\
Social concern & 0.503 & $0.657^{* *}(0.431)$ & $0.691^{* *}(0.477)$ & $0.607^{* *}(0.368)$ & 1
\end{tabular}

Notes: ${ }^{\text {a AVE }}=$ sum of squared standardized loadings/[(sum of squared standardized loadings $)+$ (sum of indicator measurement error)]; ${ }^{b}$ squared correlation; ** correlation is significant at the 0.01 level

Table V. Assessment of discriminate validity 
MABR

1,2

\section{2}

\section{Table VI.}

One-way ANOVA of differences between port corporations post hoc test of Scheffe. As shown in Table VI, mean scores of all sustainability assessment dimensions were found to have significant difference in the three container ports. Respondents from the Keelung port in the dimensions of environmental material $($ mean $=4.26)$, economic issue $($ mean $=4.44)$ and social concern $($ mean $=4.29)$ tended to gain higher mean scores than those of Taichung and Kaohsiung ports. Taichung had slightly higher mean score than those of Keelung and Kaohsiung port on environmental practices dimension.

As seen in Table VII, respondents were divided into three groups, namely, senior director or above (chairman, vice chairman, chief secretary, chief engineer, harbor master and senior director), director and supervisor (first-line manager and supervisor). The evaluation statistically differed for all sustainability assessment dimensions between these three groups based on the Scheffe test. Results indicated that senior director or above respondents had mean scores slightly higher (mean $=4.35$ ) than director and supervisor respondents on the economic issue dimension. The director and supervisor respondents tended to have higher mean scores on the environmental practices dimension.

\section{Conclusion and implications}

The objective of this research is to identify crucial sustainability criteria and examine sustainability assessment dimensions in the context of container port. Data collection was based on a questionnaire survey from 135 managers or supervisors at major container port corporations, Keelung, Taichung and Kaohsiung, in Taiwan. A total of 31 important sustainable assessment criteria were adapted from previous studies which were related to environmental, economic and social dimensions. Results revealed that

\begin{tabular}{|c|c|c|c|c|c|}
\hline $\begin{array}{l}\text { Sustainability assessment } \\
\text { dimensions }\end{array}$ & $\begin{array}{l}\text { (1) Keelung } \\
\text { port }\end{array}$ & $\begin{array}{c}\text { Port corporation } \\
\text { (2) Taichung } \\
\text { port }\end{array}$ & $\begin{array}{l}\text { (3) Kaohsiung } \\
\text { port }\end{array}$ & $F$-ratio & Scheffe test \\
\hline Env & $4.26(($ & 3 & 3.82 & $1.54^{* * *}$ & $(1,2),(1,3),(2,3)$ \\
\hline Economic issue & $4.44(0.41)$ & $4.20(0.64)$ & $4.24(0.60)$ & $1.85^{* *}$ & $(1,2),(1,3),(2,3)$ \\
\hline Environmental practices & $4.38(0.71)$ & $4.39(0.69)$ & $4.22(0.66)$ & $1.39 * *$ & $(1,2),(1,3),(2,3)$ \\
\hline Social concern & $4.29(0.51)$ & $4.14(0.61)$ & $3.95(0.59)$ & $2.19 * *$ & $(1,2),(1,3),(2,3)$ \\
\hline
\end{tabular}

Note: $* * p<0.01$
Port corporations 
social issues with respect to employee job security and safety ranked the most important sustainable assessment criterion, followed by considering environmental protection when handling cargo, facilitating to economic activities, port traffic accidents prevention and ensuring cargo handled safely and effectively. Nevertheless, respondents showed that the following sustainability items are less important: mitigating light influence on neighboring residents, considering the arrangement of vehicles when constructing port transportation system, avoiding using unpolluted land in port area, hiring minority groups and consulting interests groups when making port projects. Four sustainability assessment factors were identified as environmental material, economic issue, environmental practices and social concerns. The research findings indicated that economic issue was deemed as the most important dimension in the container port sustainability assessment context in Taiwan, followed by environmental practices, social concern and environmental material.

Theoretical and practical implications from the findings for port sustainability assessment were discussed in this research. First, although a majority of previous studies on sustainability assessment have been discussed, there is still a lack of investigation of sustainability assessment in the context of the port sector. This study not only develops sustainability assessment attributes but also highlights the important criteria of sustainability assessment. Further, this study identified four crucial sustainability assessment factors, which provide helpful information for port corporations to identify important criteria and policy of sustainability assessment.

However, this research has been limited to an evaluation of sustainability assessment criteria. Future research could conduct an effect-and-cause analysis and consider enablers (e.g. management support, internal and external collaboration) and dependable variables (e.g. organizational performance and sustainable performance) of sustainability. Moreover, this study identified crucial sustainability assessment criteria from a port operator's perspective. Future research can consider the perceptions of stakeholders which include people, community, stevedoring companies and carriers. In addition, this research only focused on Taiwan container port corporations. Future research could apply this approach in other countries or areas.

\section{References}

Acciaro, M., Vanelslander, T., Sys, C., Ferrari, C., Roumboutsos, A., Giuliano, G., Lam, J.S.L. and Kapros, S. (2014), "Environmental sustainability in seaports: a framework for successful innovation", Maritime Policy and Management, Vol. 41 No. 5, pp. 480-500, doi: 10.1080/ 03088839.2014.932926.

Anderson, J.C. and Gerbing, D.W. (1998), "Structural equation modeling in practice: a review and recommended two-step approach”, Psychological Bulletin, Vol. 103 No. 3, pp. 411-423.

Armstrong, S.J. and Overton, T.S. (1977), "Estimating nonresponse bias in mail survey", Journal of Marketing Research, Vol. 14 No. 3, pp. 396-402.

Attardi, R., Bonifazi, A. and Torre, C.M. (2012), "Evaluating sustainability and democracy in the development of industrial port cities: some Italian cases", Sustainability, Vol. 4 No. 1, pp. 3042-3065.

Bagozzi, R.P. and Yi, Y. (1988), "On the evaluation of structural equation models", Academy of Marketing Science, Vol. 16 No. 1, pp. 74-93. 
MABR

1,2

104

Behrends, S., Lindholm, M. and Woxenius, J. (2008), “The impact of urban freight transport: a definition of sustainability from an actor's perspective", Transportation Planning and Technology, Vol. 131 No. 6, pp. 693-713.

Bollen, K.A. (1989), Structural Equations with Latent Variables, John Wiley \& Sons Inc, New York.

Byrne, B.M. (2001), Structural Equation Modeling with AMOS: Basic Concepts, Applications, and Programming, Lawrence Erlbaum, New Jersey.

Carr, A.S. and Pearson, J.N. (1999), "Strategically managed buyer-supplier relationships and performance outcomes”, Journal of Operations Management, Vol. 17 No. 5, pp. 497-519.

Darbra, R.M., Pittam, N., Royston, K.A., Dabra, J.P. and Journee, H. (2009), "Survey on environmental monitoring requirements of European ports", Journal of Environmental Management, Vol. 90 No. 3, pp. 1396-1403.

Department of Transport (UK) (2009), "Ports: National Policy Statement for England \& Wales Appraisal of Sustainability (AoS) report”, available at: www.gov.uk/.../ia-evidence-basefor-ports.pdf

Fornell, C. and Larcker, D.F. (1981), "Evaluating structural equation models with unobservable variables and measurement error", Journal of Marketing Research, Vol. 18 No. 1, pp. 186-192.

Gilman, S. (2003), "Sustainability and national policy in UK port", Maritime Policy and Management, Vol. 30 No. 4, pp. 275-291.

Glavic, P. and Lukman, R. (2007), "Review of sustainability terms and their definitions", Journal of Cleaner Production, Vol. 15 No. 18, pp. 1875-1885.

Gul, D.S. and Cimen, K.C. (2012), "Port sustainability and stakeholder management in supply chains: a framework on resource dependence theory", The Asian Journal of Shipping and Logistics, Vol. 28 No., pp. 301-320.

Hair, J.F., Black, W.C., Babin, B.J. and Anderson, R.E. (2010), Multivariate Data Analysis, 7th edition, Prentice-Hall, Upper Saddle River, New Jersey.

Hu, L. and Bentler, P.M. (1995), "Evaluating model fit”, in Hoyle, R. (Ed.), Structural Equation Modeling: Issues, Concepts, and Applications, Sage, Newbury Park, CA.

Iacobucci, D. and Churchill, G.A. (2010), Marketing Research: Methodological Foundation, 10th Edition, The Dryden Press, New York, NY.

International Union for Conservation of Nature Resource (IUCN), United Nation Environment Program (UNEP), and World Wild Foundation For Nature (WWF) (1991), "Caring for the earth: Strategy for Sustainable Living, IUCN, UNEP, WWF”, Switzerland.

ISO website (2011), available at: www.iso.ch/iso/en/ISOOnline.frontpage

Kline, R. (1998), Principles and Practice of Structural Equation Modeling, The Guilford Press, New York, NY.

Koufteros, X.A. (1999), "Testing a model of pull production: a paradigm for manufacturing research using structural equation modeling", Journal of Operations Management, Vol. 17 No. 4, pp. 467-488.

McIntosh, M., Thomas, R., Leipziger, D. and Coleman, G. (2003), Living Corporate Citizenship Strategic Routes to Socially Responsible Business, Prentice Hall, London.

Marlow, P.B. (2008), "Sustainability and corporate social responsibility in shipping", IAME 2008 Annual Conference, International Association of Maritime Economists, CD file, Dalian. 
Ministry of Transportation and Communications (2016), "Monthly of traffic statistics", Taiwan, ROC, available at: www.motc.gov.tw/ch/home.jsp?id=578\&parentpath = Vol. 0,6

Nunnally, J.C. (1978), Psychometric Theory, 2nd ed, McGraw-Hill, New York.

Organization for Economic Cooperation and Development (OECD) (1990), Environmental Policies for Cities in the 1990s, OECD, Paris.

Organization for Economic Cooperation and Development (OECD) (1994), Environmental Indicators: OECD Core Set, Organization for Economic Cooperation and Development, Paris.

Pearce, D.W. and Warford, J.J. (1993), The Concepts of Sustainable Development: World Without End: Economics, Environment, and Sustainable Development, Oxford University Press, New York, NY.

Peris-Mora, E., Orejas, J.M.D., Subirats, A., Ibanez, S. and Alvarez, P. (2005), "Development of a system of indicators for sustainable port management", Marine Pollution Bulletin, Vol. 50 No. 12, pp. 1649-1660.

Pezzey, J. (1992), "Sustainable development concepts: an economic analysis", World Bank Environment Paper No. 2, The World Bank, Washington, DC.

Port of Antwerp (2016), "Sustainability report", available at: www.portofantwerp.com/sites/ portofantwerp/files/Sustainability_Report_2015.pdf

Port of Los Angeles (2013), "Sustainability report July 2011-June 2013”, available at: www. portoflosangeles.org/Publications/Sustainability_Report_2013.pdf

Ports Toronto (2016), "Sustainability report", available at: www.portstoronto.com/Toronto PortAuthority/media/TPASiteAssets/PDFs/Reports/PortsToronto_2015S ustainabilityReport_WebFinal_2.pdf

Pronk, J. and Haq, M. (1992), Sustainable Development: From Concept to Action, UNDP, New York, NY.

Sanchez-Rodriguez, C., Hemsworth, D. and Martinez-Lorente, A.R. (2005), "The effect of supplier development initiatives on purchasing performance: a structural model”, Supply Chain Management: An International Journal, Vol. 10 No. 4, pp. 289-301.

Seuring, S. and Muller, M. (2008), "From a literature review to a conceptual framework for sustainable supply chain management", Journal of Cleaner Production, Vol. 16 No. 15, pp. 1699-1710.

Shiau, T.A. and Chuang, C.C. (2015), "Social construction of port sustainability indicators: a case study of Keelung Port”, Maritime Policy and Management, Vol. 42 No. 1, pp. $26-42$.

The UN Global Compact (2010), available at: www.unglobalcompact.org/docs/news_events/8.1/ UN_Global_Compact_Annual_Review_2010.pdf

United Nations Commission on Sustainable Development (UNCSD) (1993), "National Sustainable Development Strategies", available at: www.un.org/esa/sustdev/

United Nations Conference on Trade and Development (2011), "Review of maritime transport, UNCTAD/RMT/2011”, United Nations Publication, New York, NY.

World Commission on Environment and Development (WCED) (1987), "Report of the World Commission on Environment and Development: our common future", available at: www. un-documents.net/wced-ocf.htm

Yap, W.Y. and Lam, J.S.L. (2013), "80 million-twenty-foot-equivalent-unit container port? Sustainability issues in port and coastal development", Ocean \& Coastal Management, Vol. 71 No. 2, pp. 13-25.

\section{Sustainability assessment criteria}


MABR

1,2

\section{Further reading}

Cooper, D.R. and Schindler, P.S. (2003), Business Research Methods, 8th ed., McGraw-Hill, New York, NY.

OECD website (2011), available at: www.oecd.org/home/

Port of Kaohsiung (2012), "Sustainable policy”, available at: www.khb.gov.tw/index_m.aspx? Link=InformBreaker_List.aspx? $\mathrm{fid}=63$

Sydney Ports Corporation (2006/2007), "Sustainability report", available at: www.sydneyports. com.au/_data/assets/pdf_file/0006/4839/spc_sustainability_rep_07_new.pdf

The Port of Long Beach website (2005), "Green port”, available at: www.polb.com/environment/ green_port_policy.asp

The Port of Los Angeles (2007), "Port of Los Angeles sustainability assessment and plan formulation”, available at: www.portoflosangeles.org/DOC/REPORT_Sustainability_ Assessment_Plan_Formulation.pdf

\section{Corresponding author}

Chin-Shan Lu can be contacted at: chin-shan.lu@polyu.edu.hk

For instructions on how to order reprints of this article, please visit our website: 